\title{
Joint Task Force Type 4A Myocardial Infarction
}

National Cancer Institute

\section{Source}

National Cancer Institute. Joint Task Force Type 4A Myocardial Infarction. NCI

Thesaurus. Code C119223.

Myocardial infarction associated with $\mathrm{PCl}$. (Universal definition of myocardial infarction, Kristian Thygesen, Joseph S. Alpert and Harvey D. White on behalf of the Joint ESC/ACCF/AHA/WHF T ask Force for the Redefinition of Myocardial Infarction, Eur Heart J (2007) 28 (20): 2525-2538.) 